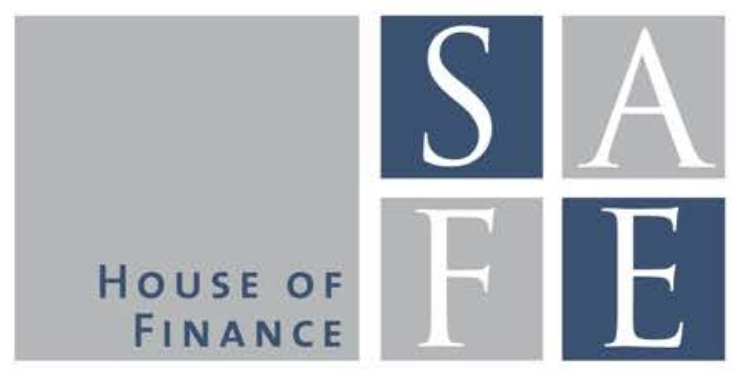

WORKING PAPER SERIES

Ester Faia - Beatrice Weder di Mauro

\title{
Cross-Border Resolution of Global Banks
}

SAFE Working Paper No. 88

SAFE I Sustainable Architecture for Finance in Europe

A cooperation of the Center for Financial Studies and Goethe University Frankfurt 


\section{Non-Technical Summary}

The insolvency of Lehman Brothers changed the world. Since then, the international regulatory community has made efforts in devising the best approach to resolving large and cross border banking groups. In almost all countries resolution authorities have opted for bail in procedures with single point of entry regimes. While the above topics are at the center of the policy and regulators debate and legislative process, there is no academic model that rationalizes the impact of those resolution regimes. We fill this gap by building a model with game-theoretic interactions. Resolution authorities choose the optimal fraction of bail-inable instruments under three regimes, SPE with cooperative or uncooperative behavior and MPE. Our model features two countries populated by banks which invest in domestic and foreign assets, raise liabilities domestically and abroad, face liquidity and equity requirements. Spillover across countries are captured by asset returns correlation as well as by cross-border liabilities. The comparison between SPE with cooperative and non-cooperative authorities allows us to appreciate the benefits of internalizing cross-country spillover. With this model we first establish that the optimal fraction of bail-inable instruments under the cooperative solution is fixed and independent from the degree of home bias. We also find that the costs for bondholders of bail-inable instruments is generally higher under non-cooperative regimes and ring-fencing. We also find that in those cases banks have ex ante incentives to reduce their exposure in foreign assets.

We also review some European case studies. While those cases have been handled prior to the implementation of the BRRD, they are anyhow instructive for two reasons. First, they show clearly the type of strategic interactions among the various national resolution authorities (see for instance the cases of Fortis and Dexia). Second, the more recent resolution cases (like the Banco de Santo Spirito) have been conducted so as to stay as close as possible to the procedures devised in the BRRD, hence those cases can be taken as examples of bail in under single point of entry. We consider all together the following case studies: Dexia, Fortis, Santo Spirito, Bank of Cyprus, Amagerbank 


\title{
Cross-Border Resolution of Global Banks*
}

\author{
Ester Faia ${ }^{\dagger}$ \\ Goethe University Frankfurt, CEPR and SAFE University of Mainz and CEPR \\ Beatrice Weder di Mauro
}

First draft: October 2014. This draft: March 2015.

\begin{abstract}
Most recent regulations establish that resolution of global banking groups shall be done according to bail-in procedures and following a Single Point of Entry (SPE) as opposed to a Multiple Point of Entry (MPE) approach. The latter requires parent holding of global groups to put up front the equity capital needed to absorb losses possibly emerging in foreign subsidiariesbranches. No model rationalized so far such resolution regime. We build a model of optimal design of resolution regimes and compare three regimes: SPE with cooperative authorities, SPE with non-cooperative authorities and MPE (ring-fencing). We find that the costs for bondholders of bail-inable instruments is generally higher under noncooperative regimes and ring-fencing. We also find that in those cases banks have ex ante incentives to reduce their exposure in foreign assets. We also examine recent case studies that help us rationalize the model results.
\end{abstract}

JEL: G18, F3.

Keywords: single point of entry, multiple point of entry, strategic interaction of regulators, financial spillover, financial retrenchment.

\section{Introduction}

"The Single Point of Entry versus Multiple Point of Entry resolution strategy distinction may be the most important innovation in banking policy in decades" Paul Tucker

The insolvency of Lehman Brothers changed the world. Governments had to mobilize enormous rescue packages. In this efforts a fundamental flaw of the international financial architecture became apparent, namely the inability of national supervisors to orchestrate orderly bank resolutions across borders. Since then, the international regulatory community has made efforts in devising the best approach to resolving large and cross border banking groups.

\footnotetext{
${ }^{*}$ This research has been supported by the DG-ECFIN grant "Forward to a New Nomal". Ester Faia gratefully acknowledges research support from the Research Center SAFE, funded by the State of Hessen initiative for research LOEWE.

${ }^{\dagger}$ Goethe University Frankfurt, faia@wiwi.uni-frankfurt.de.
} 
First, in almost all countries resolution authorities have opted for bail in procedures. The underlying idea behind bail in is that of identifying ex ante an institution and a set of investors who would bear losses in case the liabilities of the banking group would exceed the assets. Bail in procedures have several merits. They avoid the long delays and uncertainty of bankruptcy procedures, thereby reducing the risk of bank runs and panics. Higher transparency also facilitates the pricing of bail-inable bonds. Moreover, bail in procedures do not carry risks of moral hazard and risk taking as it is the case for bail-outs. Finally, while bail-outs eventually impose the burden of banks' losses on tax payers, bail-in procedures allow regulators to impute losses upon investors who were likely aware of having invested in risky assets.

Notice that bail in procedures require identifying ex ante the entity (within each banking group) which should provide up front enough capital and liquidity to be able to face losses in case the banking group or one of the subsidiaries would default. In this respect both the US and the European regulators have decided to follow the so called Single Point of Entry approach (SPE hereafter), which implies that the entity viable to bear losses should be the parent holding company of any banking group. Losses would then ultimately be borne by equity holders and bondholders (of unsecured debt) of parent holdings ${ }^{1}$. It is worth stressing that the success of the SPE approach will largely depend upon the willingness of national supervisors to cooperate in the assignment of cross border losses. In this respect the landscape shows mixed degrees of commitment. The Euro area has moved toward a fully coordinated approach: the Bank Restructuring and Resolution Directive of 2014 (BRRD) indeed harmonizes bail-in resolution procedures across euro area countries. Other major financial centres like the US and the UK have both tended to go for national ring fencing approaches. In principle, the Financial Stability Board (FSB) is in charge of cooperative solutions at the global level, but FSB can only make recommendations. Despite the recommendation to follow cooperative solutions in practice resolution of cross border banking groups is complex and agreement in the assignment of losses is difficult to reach. First, confronted with a foreign shock, national authorities are tempted to ring fence locally and will not internalize the cost of financial instability elsewhere ${ }^{2}$. If national authorities care primarily about their respective national parlia-

\footnotetext{
${ }^{1}$ In Europe this choice was also motivated by the need to impute losses to investors of large banking groups, which had taken aggressive and risky investment strategies through their subsidies in fragile countries.

${ }^{2}$ Schoenmaker (2013 p. 45) gives an illustration of such behaviour. In 1991 an international bank called BCCI went bankrupt and the US supervisor immediately ring fenced the assets on the US branch to pay off US depositors.
} 
ment, creditors or taxpayers, then cross-border cooperation will always fall short in time of stress. Second, it is difficult and politically unfeasible for global banks to transfer resources among their subsidiaries efficiently in good times or to shift resources to a troubled subsidiary from a healthy subsidiary in bad times. The regulator of a country hosting a healthy subsidiary would be unlikely to allow the transfer of resources from that subsidiary to a troubled one abroad. This implies that in practice a multiple point of entry approach (MPE hereafter), according to which losses are to be imputed to the local subsidiary/branch, is more likely to be implemented.

While the above topics are at the center of the policy and regulators debate and legislative process, there is no academic model that rationalizes the impact of those resolution regimes. We fill this gap by building a model with game-theoretic interactions. Resolution authorities choose the optimal fraction of bail-inable instruments under three regimes, SPE with cooperative or uncooperative behavior and MPE. Our model features two countries populated by banks which invest in domestic and foreign assets, raise liabilities domestically and abroad, face liquidity and equity requirements. Spillover across countries are captured by asset returns correlation as well as by crossborder liabilities. The comparison between SPE with cooperative and non-cooperative authorities allows us to appreciate the benefits of internalizing cross-country spillovers. With this model we first establish that the optimal fraction of bail-inable instruments under the cooperative (SPE) solution is fixed and independent from the degree of home bias (since now on by degree of home bias we mean the one in banks' liabilities). Results also show that the fraction of bail-inable bonds under the non-cooperative solution is always larger than the one under the cooperative solution. This fraction becomes even infinite under the non-cooperative solution when the degree of home bias is half. Under the non-cooperative solution supervisors do not internalize the cross-country spillover of their actions, therefore a prisoner dilemma (symmetric) equilibrium implies that costs borne by bondholders are higher than under cooperative solution. Losses to bondholders under MPE are the same than under cooperative SPE when the degree of home bias is nil (banks are fully exposed in foreign liabilities), but are higher when the degree of home bias approaches one. MPE corresponds to ring fencing, hence domestic bondholders bear higher losses when banks fail to risk-share liabilities ex ante.

The choice of the resolution regime has also consequences for financial integration and glob- 
alization. Under SPE the parent holding remains fully liable for subsidiaries' losses or for losses in foreign assets. Banks also know that under the non-cooperative solution losses to bondholders are larger, therefore equity capital needed to cover losses is also larger. The higher (ex post) losses, and the higher capital buffer needed to cover such losses, discourage banks (ex ante) from engaging in cross-border activity. Indeed with our model we find that investment in foreign assets is smaller under the SPE non-cooperative regime. Equally the move from an MPE to an SPE regime can induce financial retrenchment. We find that this is the case only when the degree of exposure to foreign liabilities is below a certain threshold. In this case indeed under the SPE regime most of the losses are borne by domestic bondholders; this induces banks to reduce also the exposure to the risk of losses from foreign assets.

We also review some European case studies. While those cases have been handled prior to the implementation of the BRRD, they are anyhow instructive for two reasons. First, they show clearly the type of strategic interactions among the various national resolution authorities (see for instance the cases of Fortis and Dexia). Second, the more recent resolution cases (like the Banco de Santo Spirito) have been conducted so as to stay as close as possible to the procedures devised in the BRRD, hence those cases can be taken as examples of bail in under single point of entry. We consider all together the following case studies: Dexia, Fortis, Santo Spirito, Bank of Cyprus, Amagerbanken.

The only previous paper which considered the issue of cooperative versus non-cooperative banks' resolution regimes is Niepman and Schmidt-Eisenlohr [6] which however focuses on banks' bail out and examine a banking sector modeled along the lines of Diamond and Dybvig [2]. In this paper indeed the author actually on the problem of managing liquidity shortage for global banking groups through public interventions. The Geneva report [1] focuses on the policy debate related to the optimal design of resolution regimes and reviews a few cases. Also this report focuses on resolutions carried via bail-outs, while the goal of our paper is to address the design and implementation of bail-in clauses for global banking both through a theoretical model and through a case study analysis.

The rest of the paper is divided as follows. The next subsection gives a visual inspection of the single versus the multiple point of entry resolution procedures. Section 2 describes the model 
and its solution. Section 3 reviews all the case studies and makes a parallel with model results. Section 4 concludes. References follow.

\subsection{Visual Inspection of the Single versus the Multiple Point of Entry}

A crucial aspect of our analysis relates to the comparison of the resolution procedures under single and multiple point of entry. Before laying down the model, it is instructive to give a visual inspection of the working of those two alternative resolution mechanism.

In principle the single point of entry is an institutional innovation, that aims at overcoming cooperation failure, by establishing the responsibilities (which authority "enters") and the type of intervention ex ante. Single point of entry attempts to implement a global solution by working downwards from the top company (Bank Holding) irrespective of where the initial loss occurred. Figure 1 shows the intra-group flows in a stylized single point of entry resolution. First, the subsidiary in country B suffers a loss. The loss is then transferred within the group to the bank holding company that now fails to fulfil capital requirements. The home country authorities take over and applies bail in: equity and subordinated debt are written off, senior (bond) debt is converted into equity. The proceeds are used to recapitalize the subsidiary in country B. If the loss absorbing capital at the holding company is sufficiently large, subsidiaries of the group in other countries will be unaffected. If the loss absorbing capital proves insufficient, the home country authority broadens the bail in base or sells assets in the rest of the group (including in subsidiaries in the home and other countries). The home country authority follows a global resolution plan, which has identified the assets that can be sold while minimizing value destruction, business disruption and systemic risk. Thus, the home country authority is implementing the most efficient solution globally by pooling the group's assets and liabilities since the single point of entry operates like a global resolution authority.

Key regulators stress that one of the advantages of the single point of entry approach is that it avoids the need to commence separate territorial insolvency proceedings, which could be disruptive and difficult to coordinate. Ideally, the home country authority assumes command of a global resolution syndicate and implements optimal burden sharing across the group and jurisdictions. It minimizes financial stability concerns and supports international intermediation through internal capital markets in the group. Financial fragmentation is avoided because the bank group becomes 


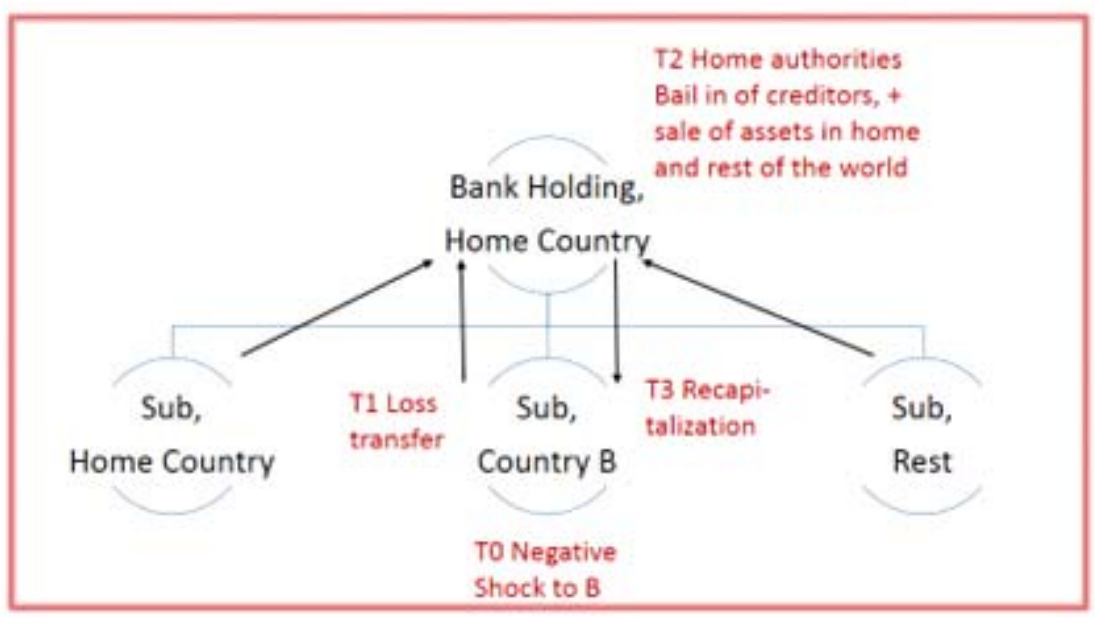

Figure 1:

global, both in life and in death.

This global optimum may break down, however, if different national supervisors pursue different goals and give preference to the subsidiaries located in their own country. The result, as explained by Huertas (2014 p. 124) is that: "In theory, all subsidiaries are equal. In practice, they are not" . In particular, the subsidiary located in the home country, i.e. in the same jurisdiction as the bank holding company is likely to receive a more favorable treatment from home supervisors than subsidiaries located in other countries. This suspicion would make other countries' authorities reluctant to accept the leadership of the home country. If the home country is primarily concerned about financial stability at home, in crisis cooperation is highly likely to break down.

Figure 2 illustrates single point of entry resolutions in a non-cooperative setting. Again, the point of departure is a loss in a subsidiary in country B. Again, the loss is transferred to the bank holding company and the home authority takes charge of the entity. If loss absorbing capital at the holding is lacking, the home authority attempts to sell eligible assets or bail in eligible liabilities abroad. At this stage, other country authorities announce that they are not willing to import the 


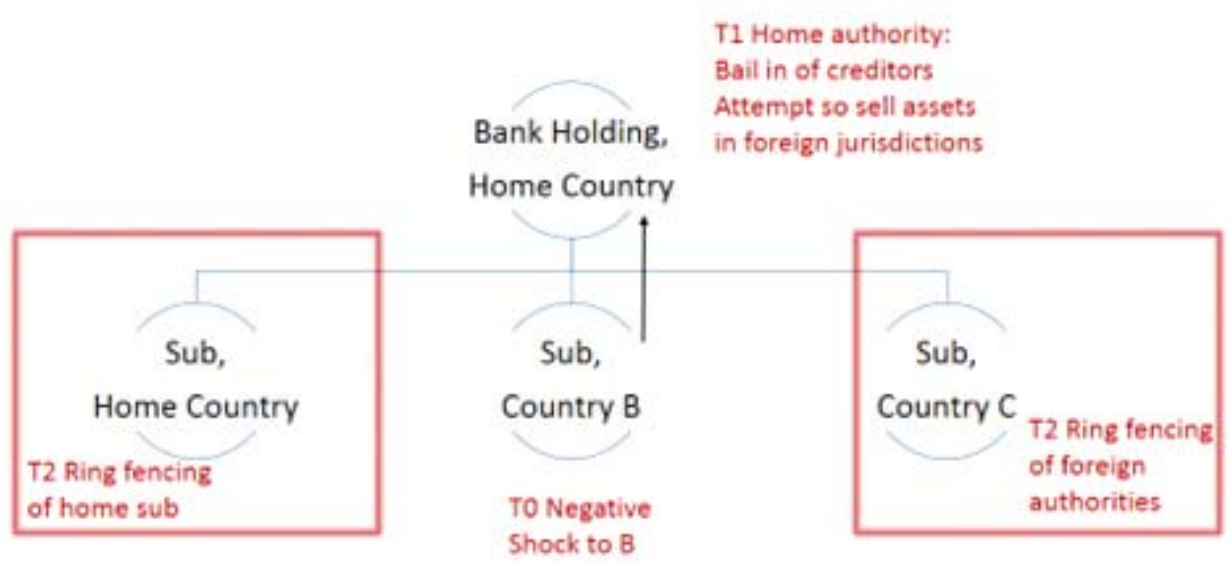

Figure 2:

shock from country B and proceed to ring-fence the subsidiary located in their country. The home country authority also ring-fences the home subsidiary to minimize the threat to financial stability at home. Now, the subsidiary in country B fails in a disorderly fashion or receives a bail out from either B or home. The latter could be the case if the disorderly failure of the subsidiary in B has indirect contagion effects on the entire group (through franchise or confidence effects) and thus on other countries.

Figure 3 shows a multiple point of entry resolution. Following a loss in country B, the local authorities take over the subsidiary and proceed to bail in creditors. If loss-absorbing capital at the local level is sufficient, the subsidiary is recapitalized. If it is not sufficient, the subsidiary is liquidated causing risks to financial stability in country B. The shock might be contained in the country; however, it is possible that the rest of the group is affected through loss of reputation, franchise and confidence. This could prompt the need for intervention in other countries too. This latter consideration suggests, that the financial stability properties of a multiple point of entry resolution may not be contained in the originating country. 


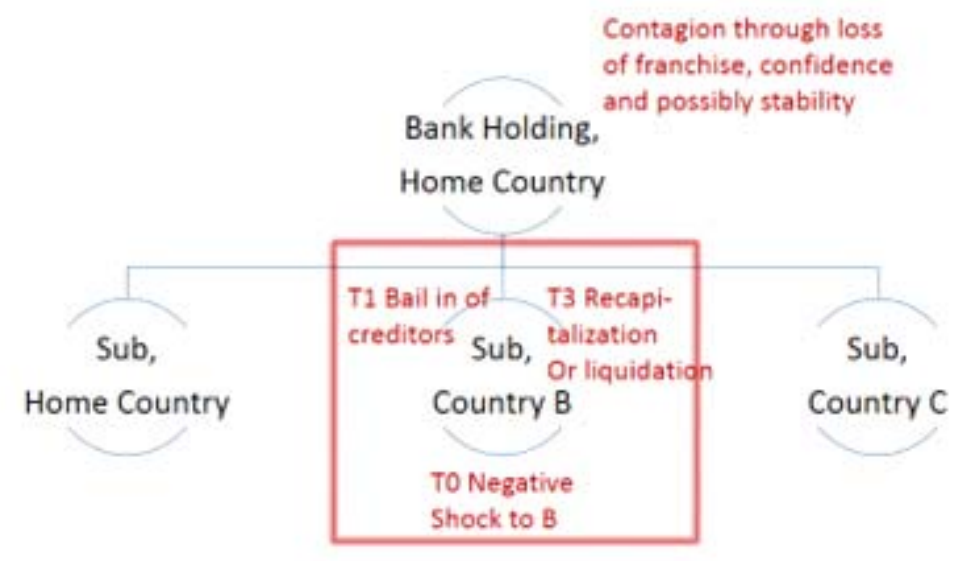

Figure 3:

Overall, the multiple point of entry is a way of implementing the ring fencing approach before crises. For the banking group it means that any distressed part will be detached from the group. This would cause problems if there are critical functions and services that are shared across the group. Such functions would therefore already have to be separated out in normal times to minimize disruption in crises. For the same reason, cross border exposures, guarantees and hedging will have to be minimized. In each jurisdiction, subsidiaries will have to raise local funding and provide the full set of legal entity specific financial information. Consequently, the banking group will have to disintegrate already in normal times: banks become national both in life and in death.

At the system level, an uncertain advantage of containing contagion comes at the certain cost of financial disintegration. 


\section{Two Country Model with Cross-Border Banking under Single Point of Entry Resolution}

Our model is comprised of two countries which we label $i$ and $j$. A continuos of countries can be nested in our model. In each country there is a banking group which has activities in the foreign country and there is also a resolution authority which must handle groups under distress. Resolution authorities in the two countries can act in a coordinated fashion or in uncoordinated fashion. Banks have cross-border assets, have cross-border liabilities and have to fulfill equity requirements. Assets are subject to shocks both domestically and abroad and those shocks are correlated. Define $A^{i}$ the domestic asset held by bank resident in country $i$ and $A^{i, *}$ as the foreign asset held by the same bank. Assets have returns respectively $R^{A, i}$ and $R^{A *, i}$ which are random and follow distributions $f\left(R^{A, i}\right)$ and $f\left(R^{A *, i}\right)^{3}$. Banks raise funds through deposits ${ }^{4}$ and other short term liabilities domestically, $D^{i}$; on those liabilities banks pay a return, $R^{D}$. Returns on deposits are assumed for the time being equal across countries: this follows from the assumption that risk free returns are normally equalized across countries and from the fact that for the time being we do not assume any stochastic structure on those returns. Banks can also raise short term liabilities in the foreign country.

Given this background, cross-border spillover take two forms. First, since assets' returns are correlated across countries negative shocks to foreign assets produce contagion effects also to domestic assets. Second, in bail in procedures loss assignments also involve investors of foreign countries: this fact might trigger strategic behavior on the side of the national resolution authorities which might wish to protect the investors resident in their own country.

Banks determine assets and liabilities to fulfill liquidity and equity constraints. First, banks fulfill a liquidity constraint:

$$
R^{A, i} A^{i}+R^{A *, i} A^{i, *} \geq R^{D}\left(\mu D^{i}+(1-\mu) D^{i}\right)
$$

where $\mu$ represents the fraction of liabilities, $D^{i}$, that bank $i$ raises domestically. When returns

\footnotetext{
${ }^{3}$ Those distributions could be a simple binomial distribution with two events, bad and good state, or continuos distributions with decreasing hazard rates (uniform or logistic).

${ }^{4}$ For simplicity we assume that there are only uninsured deposits. First, insured deposits are actually a small fraction of all short term liabilities. Second, if all liabilities were fully insured shocks to asset returns would not pose any default challenge for the bank.
} 
on assets fall short of the return on short term liabilities (because of a negative shock from the distributions $f\left(R^{A, i}\right)$ and $\left.f\left(R^{A *, i}\right)\right)$ a run or panic on the banking system emerges. Notice that the probability of a run is given by the joint distribution:

$\Theta=f\left(R^{A, i} \mid R^{A, i} A^{i}+R^{A *, i} A^{i, *} \leq R^{D}\left(\mu D^{i}+(1-\mu) D^{i}\right)\right) f\left(R^{A *, i} \mid R^{A, i} A^{i}+R^{A *, i} A^{i, *} \leq R^{D}\left(\mu D^{i}+(1-\mu) D^{i}\right)\right)$

When runs or panics happen banks start to sell assets until they meet the repayment of liabilities. Liquidating assets usually entails a cost of early project conclusion. We assume that the cost on liquidating foreign assets is larger than the cost of liquidating domestic assets. This assumption allows us to avoid the equilibrium in which the bank simply walks away from the foreign country. In the limit we can assume that the cost applies only to the foreign asset liquidation. Let's define this cost as a fraction of total assets: $c A^{i, *}$.

Banks shall also fulfill an equity regulatory requirements or a VaR constraint which can be written as follows:

$$
C R=\frac{A^{i}+A^{i, *}-\left(\mu D^{i}+(1-\mu) D^{i}\right)}{A^{i}+A^{i, *}} \geq \gamma
$$

In need of liquidity banks start to sell assets, however they can do it only until the capital requirements is violated. If this happens, banks go technically on default. Notice that the above constraint is based on the assumption that we are under a single point of entry procedure: indeed it is the parent holding resident in country $i$ that must put up-front enough capital for both domestically as well foreign held assets. The constraints of the foreign banks read symmetrically.

\subsection{Regulatory Regimes. Cooperative versus non cooperative regimes under SPE or MPE}

If the possibility of banks' default materializes the resolution authority intervenes through bail in procedures. Resolution authorities can intervene in a coordinated or in an uncoordinated fashion. Bail-ins are usually implemented through some complex procedures which involve pecking order of loss bearing investors and transfer of short term liabilities into equities. In our model bail is given by the transfer of a fraction $\xi$ of short term liabilities into banks equity capital, $P B K^{i, i}$, up to the point in which constraint 3 is satisfied. In the non cooperative solution the regulatory authority of each country chooses a fraction $\xi$ out of short term liabilities held domestically, namely $\mu D^{i}$ for 
country $i$ and $(1-\mu) D^{i}$ for the foreign country. In the cooperative solution the resolution authority chooses a fraction $\xi$ of the total $\left(\mu D^{i}+(1-\mu) D^{i}\right)$.

Resolution authorities choose $\xi$ in the bail-in case to minimize a loss function. The resolution authority faces a trade-off between the cost imposed to depositors whose liabilities are transformed into equities, which we proxy with $\left(\xi \mu \frac{D^{i}}{A^{i}+A^{i, *}}\right)^{2}$, and the deviation of the actual equity capital from the regulatory target, which we also call the capital shortfall and is proxied by $(C R-\gamma)^{2}$. A higher $\xi$ means that a larger fraction of investors are forced into accept risky equities in exchange of liquid short term liabilities or demand deposits. On the other side a higher $\xi$, by injecting more equities, allows the bank to meet its regulatory capital requirement.

In the non cooperative regime each national regulator decides the fraction of domestic short term liabilities, $\xi$, that shall be transformed into bank equities, by taking as given the fraction chosen by the other national regulator, $\xi^{*}$. The resulting equilibrium would be a standard Nash prisoner's dilemma. Hence the regulator of country $i$ chooses $\xi$ to minimize:

$$
L_{\text {bailin }}^{i}=\left(\xi \mu \frac{D^{i}}{A^{i}+A^{i, *}}\right)^{2}+(C R-\gamma)^{2}
$$

subject to:

$$
C R=\frac{A^{i}+A^{i, *}-\left(\mu(1-\xi) D^{i}+(1-\mu)\left(1-\xi^{*}\right) D^{i}\right)}{A^{i}+A^{i, *}} \geq \gamma
$$

The optimization problem can be written as follows:

$$
\operatorname{Min}_{\xi}\left(\xi \mu \frac{D^{i}}{A^{i}+A^{i, *}}\right)^{2}+\left(\frac{A^{i}+A^{i, *}-\left(\mu(1-\xi) D^{i}+(1-\mu)\left(1-\xi^{*}\right) D^{i}\right)}{A^{i}+A^{i, *}}-\gamma\right)^{2}
$$

The first order conditions with respect to $\xi$ delivers the following solution:

$$
\xi=\frac{(\gamma-1)\left(A^{i}+A^{i, *}\right)}{2 \mu D^{i}}+\frac{1}{2}+\frac{(1-\mu)}{2 \mu}\left(1-\xi^{*}\right)
$$

The optimization problem of the foreign resolution authority is just symmetric. Notice that we are assuming that the two countries are symmetric with respect to the degree of home bias, so that $\mu=\mu^{*}$. To simplify expressions let's define $\Lambda=\frac{(\gamma-1)\left(A^{i}+A^{i, *}\right)}{2 \mu D^{i}}, \delta=\frac{(1-\mu)}{\mu}$. The optimal reaction function of the foreign supervisory authority delivers the following expression $\xi^{*}=\Lambda+\frac{1}{2}-\delta(1-\xi)$ (recall that given $\mu=\mu^{*}$, we also have $\Lambda=\Lambda^{*}, \delta=\delta^{*}$ ). To obtain the Nash equilibrium level of the optimal $\xi$ (in equilibrium both authorities will choose the same fraction of deposits to be bailed 
in) is given by:

$$
\begin{aligned}
\xi^{N C} & =\Lambda \frac{2}{2-\delta}+\frac{(1+\delta)}{(2+\delta)}= \\
& =\frac{(\gamma-1)\left(A^{i}+A^{i, *}\right)}{D^{i}(2 \mu-1)}+\frac{1}{2}
\end{aligned}
$$

In the cooperative regime a single resolution authority chooses $\xi$ to minimize:

$$
L_{\text {bailin }}^{i}=\left(\xi \frac{\left(\mu D^{i}+(1-\mu) D^{i}\right)}{A^{i}+A^{i, *}}\right)^{2}+(C R-\gamma)^{2}
$$

subject to the constraint 5 . The first order condition reads as follows:

$$
\xi\left[\frac{\left(\mu D^{i}+(1-\mu) D^{i}\right)}{A^{i}+A^{i, *}}\right]^{2}+(C R-\gamma)\left[\frac{\left(\mu D^{i}+(1-\mu) D^{i}\right)}{A^{i}+A^{i, *}}\right]=0
$$

Rearranging one gets the optimal level of bail-inable deposits which is given by:

$$
\xi^{C}=\frac{(\gamma-1)\left(A^{i}+A^{i, *}\right)}{2 D^{i}}+\frac{1}{2}
$$

Let's now compare the optimal fraction of bail-inable bonds under the two SPE regimes.

Proposition 1. When $\mu \leq 1$,namely when the degree of home bias in banks' liabilities is maximum, $\xi^{N C} \geq \xi^{C}$. When $\mu=\mu^{*}=\frac{1}{2}$, namely for intermediate degrees of home bias, $\xi^{N C} \rightarrow \infty$..

The proof of the above proposition follows directly from algebraic comparison of equations 8 and 12 .

To rationalize the result from Proposition 1 recall that under the non-cooperative solution the resolution authority does not internalize the spillovers. that its own actions produce on the foreign bondholders. Each supervisory authority acts myopically and does not internalize aggregate costs. This implies that in the prisoner's dilemma equilibrium the costs for bondholders in each country are higher than under the cooperative solution.

\subsection{The Model under Multiple Point of Entry}

Under multiple point of entry the bank is required to hold equity capital in both countries to cover for losses on assets. Practically global banks are de-coupled into two branches, the one of the domestic country and the one of the foreign country. Banks therefore face two different equity constraints in each country and for each branch. Therefore banks decide to hold equity capital in 
each country relatively to the assets invested in each country branch. We also assume that raising capital in the periphery country entails some sunk cost, $\bar{E}$ : this cost captures the idea that bank capital raised in peripheral countries might be of lower quality. The two constraints would read as follows:

$$
\begin{gathered}
C R^{i}=\frac{A^{i}-\mu D^{i}}{A^{i}} \geq \gamma^{i} \\
C R^{j}=\frac{A^{i, *}-(1-\mu) D^{i}}{A^{i, *}}-\bar{E} \geq \gamma^{j}
\end{gathered}
$$

$\mu$ represents the fraction of short term liabilities which the bank allocates for investment in each country. This fraction shall be set exogenously using home bias metrics in deposits. Constraints 13 and 14 can be interpreted as follows. In each country the regulator sets two different regulatory requirements and the bank fulfills the constraints by raising capital in each country separately. Under the banking union this might be justified by saying that macro-prudential regulation is still in the hands of national supervisors and because of this the overall equity requirement is different across euro area members. Of course one strong assumption is that banks cannot move capital across countries. This might be a strong assumption, but not unrealistic if we think of the case of Unicredit and its German subsidiary: capital or liquidity could not be moved due to Bafin regulation.

Under the multiple point of entry regulation the resolution authority of each country is delegated to resolve the bank branch resident in their own country. Practically this case corresponds to ring fencing. And by construction in this case the optimal design of resolution procedures is implemented under non cooperative regime. In country $i$ the resolution authority chooses $\xi$ to minimize:

$$
\operatorname{Min} L_{b a i l i n, M P E}^{i}=\left(\xi \mu \frac{D^{i}}{A^{i}}\right)^{2}+\left(C R-\gamma^{i}\right)^{2}
$$

subject to:

$$
C R^{i}=\frac{A^{i}-\mu(1-\xi) D^{i}}{A^{i}} \geq \gamma^{i}
$$

The first order condition in this case reads as follows:

$$
\xi^{i, M P E}=\frac{(\gamma-1)\left(A^{i}\right)}{2 \mu D^{i}}+\frac{1}{2}
$$


Notice that under MPE there is no interaction between the optimal fraction of bail-inable deposits in country $i$ and country $j$. The authority of the foreign country chooses $\xi^{*}$ to:

$$
\operatorname{MinL}_{\text {bailin }, M P E}^{j}=\left(\xi^{*}(1-\mu) \frac{D^{i}}{A^{i}}\right)^{2}+\left(C R-\gamma^{j}\right)^{2}
$$

s. to:

$$
C R^{j}=\frac{A^{i, *}-(1-\mu)\left(1-\xi^{*}\right) D^{i}}{A^{i, *}}-\bar{E} \geq \gamma^{j}
$$

The first order conditions in this case reads as follows:

$$
\xi^{j, M P E}=(\gamma-1+\bar{E}) \frac{A^{i, *}}{2(1-\mu) D^{i}}+\frac{1}{2}
$$

Notice that the optimal fraction of bail-inable deposits is higher in the foreign country than in the home country. This can be seen by comparing equations 17 and 20 . The intuition for this result is as follows. Since equity capital in the foreign country features a cost (part of the capital is wasted due to lower quality), the resolution authority of the foreign country must bail in a higher fraction of short term liabilities to allow the foreign branch of the bank to meet the equity requirement.

Proposition 2. $\xi^{i, M P E}=\xi^{C}$ if and only if $A^{i, *}=0$ and $\mu=1$. And $\xi^{i, M P E} \geq \xi^{C}$ if $(1-\mu) \geq \frac{A^{i, *}}{A^{i}}$

The proof of proposition 2 follows from comparing equations 12 and 17 .

Intuitively if the degree of home bias in country $i, \mu$, is maximum and if there is no extra costs from raising capital abroad, we approach the case of a large closed economy. In this case the optimal fraction of bail-inable instruments is the same in the ring fencing and in the fully cooperative approach. Generally speaking the optimal fraction of bail-inable instruments in country $i$ under MPE is larger than the optimal one under SPE with fully coordinated regimes whenever the degree of home bias of country $i$, namely $\mu$, is smaller than $\frac{A^{i, *}}{A^{i}}-1$. Intuitively if banks are globally more exposed on the assets side than on the liabilities side, the impact of changes in foreign assets on the loss from capital shortfall out-weights the loss from the loss to domestic investors. Because of this the resolution authority will expropriate a larger fraction of short term liabilities in order to cover for the capital shortfall.

Proposition 3. $\xi^{j, M P E} \geq \xi^{C}$ if and only if $(1-\mu) \leq \frac{(\gamma-1+\bar{E}) A^{i, *}}{[(\gamma-1])\left(A^{i}+A^{i, *}\right)}$. If $(1-\mu) \rightarrow 1$ and $\bar{E}=0$, then $\xi^{j, M P E}=\xi^{C}$. If $\mu \rightarrow 1$, then $\xi^{j, M P E} \rightarrow \infty$. 
The proof of proposition 3 follows directly from comparing equations 12 and 20 . Intuitively the resolution authority of country $j$ will generally be forced to bail in a higher fraction than the resolution authority of country $i$ since equity capital raised in country $j$ is of lower capital (it is subject to a cost $\bar{E}$ ). The fraction of bail-inable instruments for country $j$ will then be higher than the one optimally chosen by the cooperative authority under SPE if the home bias in country

$j,(1-\mu)$, is small enough. In this case ex ante ring fencing prevents banks from implementing full risk sharing on liabilities; ex post this forces the resolution authority to tax foreign investors more heavily in order to compensate for the capital shortfall. The case in which the degree of home bias is infinite and there is no cost of raising capital in the foreign country (raising capital in country $i$ is equivalent to raise capital in country $j$ ) corresponds in the limit to the closed economy: therefore in this case $\xi^{j, M P E}=\xi^{C}$. At last, when the degree of home bias is nil, banks are fully dependent from liabilities in country $i$. In this case the resolution authority can only rely on an infinitesimal fraction of domestic liabilities to cover for the ex post capital shortfall, hence it needs to tax domestic investors in full.

\subsection{Banks' Globalization Decisions in each Prudential Regime}

In our model banks determine their portfolio simply based on regulatory or VaR constraints. We can therefore substitute the optimal fraction of bail-inable instrument in each regime (SPE with cooperation, SPE with no cooperation, MPE) in the equity requirement and solve for the optimal quantity of foreign assets (for given liabilities in both countries and for given level of domestic assets). We start from the single point of entry. In this case given the equity requirement, namely equation 3, we obtain the optimal level of foreign assets which reads as follows:

$$
A^{i, *}=-A^{i}+\frac{(1-\xi)\left(\mu D^{i}+(1-\mu) D^{i}\right)}{(1-\gamma)}
$$

there is clearly a negative relation between the level of foreign asset investment and the optimal fraction of bail-inable instruments. The negative relation is fairly intuitive. Banks will have lower incentive to invest in the foreign country if they realize that this choice entails larger resolution costs for banks' bondholders. Using the results obtained in Proposition 1, we have the following results for the optimal degree of globalization in each of the two policy regimes with SPE regulation.

Proposition 4. For any value of $\mu=1,\left(A^{i, *}\right)^{N C} \leq\left(A^{i, *}\right)^{C}$. 
The proof of the above proposition follows directly from substituting $\xi^{N C}$ and $\xi^{C}$ into 21 . The results in proposition 4 are fairly intuitive.

To analyze the comparison for the optimal level of foreign assets between the single and the multiple point of entry we focus on comparing the solution under MPE uncoordinated regime and the SPE coordinated regime. As before we must recall that the optimal fraction, $\xi$, under MPE differs across countries. We will then compare the optimal fraction, $\xi^{i, M P E}$, for country $i$ under the MPE against the optimal fraction, $\xi^{C}$, under SPE-cooperative solution. The comparison with the optimal fraction for country $j$ would just be symmetric.

Proposition 5. $\left(A^{i, *}\right)^{M P E} \leq\left(A^{i, *}\right)^{S P E, C}$ if $\mu \geq 2-\frac{A^{i}(1-\gamma)}{D^{i}}$.

Proof. To compare the equilibrium level of foreign assets under the MPE and the SPE with cooperative authorities we must first substitute equation 12 into the equity constraint 21 and equation 17 foreign into the equity constraint 16. We then obtain the following expression for the level of foreign assets of domestic banks:

$$
\begin{aligned}
& \left(A^{i, *}\right)^{S P E, C}=\frac{D}{(1-\gamma)}-A^{i} \\
& \left(A^{i, *}\right)^{M P E}=\frac{\mu D}{2(1-\gamma)}-A^{i}
\end{aligned}
$$

By comparing equations 22 and 23 we find that $\left(A^{i, *}\right)^{M P E} \geq\left(A^{i, *}\right)^{S P E, C}$ if $\mu \leq 2-\frac{A^{i}(1-\gamma)}{D^{i}}$.

The above result shows that banks invest less in foreign assets under the SPE regime only when the degree of exposure to foreign liabilities is below a certain threshold. In this case indeed under the SPE regime most of the losses are borne by domestic bondholders; this induces banks to reduce also the exposure to the risk of losses from foreign assets.

\subsection{Case Studies of Banks Resolutions in Europe}

So far most resolutions have taken place via bail out procedures. More recently and following the BRRD directive we have witnessed a number of bail in procedures, mostly under the single point of entry. We review some of those cases with the goal of assessing a link with the logic of our model. One caveat that shall be stressed if that given the same nature of resolutions (they do not take place so frequently) it is not possible to construct a full fledged dataset through which to test 
out theories statistically. We must therefore rely on the qualitative description of the most recent case studies and on some quantitative proxies for the losses borne (either by the public sector or by private investors) during the resolution procedure. In the description of the cases we account for the partition of losses among domestic parent holding and cross-border subsidiaries.

The following table summarizes the amount of money involved in recapitalizations and/or resolution of some European banks. For details and sources on each case see below footnotes to each case.

\begin{tabular}{|c|c|c|c|c|}
\hline \multicolumn{5}{|c|}{ Table 1. Recapitalization values/losses (in billions of $€$ ) } \\
\hline Bankia & Dexia & Bank of Cyprus & Amagerbanken & Fortis \\
\hline 24.6 & 11.5 & 4.5 & 0.9 & 35.59 \\
\hline
\end{tabular}

\section{Bankia $^{5}$}

The recapitalization value, undertaken via several decisions of the Fund for Orderly Bank Resolution ("FROB"), amounts to $€ 24.6$ billion (see Fondo de Reestructuracion Ordenada Bancaria, 7 December 2014) ${ }^{6}$. This is done via BFA, the parent holding company of Bankia, which is controlled by the state via the FROB. This case can therefore be classified as a case of bail in with single point of entry.

\section{Dexia $^{7}$}

The Dexia Group has reported significant losses in the last years $(€ 3.33 \mathrm{bn}, € 11.64 \mathrm{bn}, €$ 2.87 bn and $€ 1.08$ bn in 2008, 2011, 2012 and 2013 respectively). The initial losses in 2008 was covered through state aid. The governments of Belgium and France capitalized the group for an amount of $€ 6 \mathrm{bn}^{8}$, of which $€ 5.2$ was deemed as state aid by the European Commission (see page 4 in the Official Journal of the European Union, vol. 57, 12 April 2014); each government contributed with half of the bill ${ }^{9}$. An important part of these funds were used by Dexia Group to

\footnotetext{
${ }^{5}$ Sources of data: Bankia, FROB, European Commission (II), Finpolconsult.

${ }^{6} \mathrm{An}$ alternative estimate of losses is given by for the recapitalization cost by BFA/Bankia: for instance the Commission reports a number of $€ 22$ bn, see State Aid Scoreboard http://ec.europa.eu/competition/state_aid/scoreboard/financial_economic_crisis_aid_en.html\#tables.

${ }^{7}$ Sources: Dexia Annual Reports, Eüropean Commission (II, III, IV).

${ }^{8}$ Additional measures at this stage were refinancing guarantees for $€ 135$ bn and impaired asset measures for $€$ $3.2 \mathrm{bn}$.

${ }^{9}$ We must report that we have also gathered somehow different figures on those losses. In the letter of 19 November 2008, C(2008)7388 to the Member states the overall reported amount is $€ 6.4$ bn, with Belgium and France providing $€ 3 \mathrm{bn}$ each and Luxembourg providing the rest. In page 4 of the Official Journal of the European Union from 2014 no mention is made to the contribution by Luxembourg. At last in the press release from 2012, see http://europa.eu/rapid/press-release_IP-12-1447_en.htm, in which the Commission approves the major restructur-
} 
recapitalize the most troubled subsidiary, Dexia Crédit Local, to the tune of $€ 3.5 \mathrm{bn}$; an additional $€ 2.5$ bn were used to capitalize the subsidiary Dexia Bank (see page 223 in the Official Journal of the European Union, vol. 57, 12 April 2014).

Following the losses in 2011 a major restructuring and orderly resolution plan was designed, which continues today. The plan involved disposing of the major subsidiaries and a major shrinking of the balance sheet size. As part of the orderly resolution plan, which was eventually approved by the Commission on Dec. 28 2012, a second recapitalization by the Belgian and French governments was undertaken. This recapitalization was of $€ 5.5 \mathrm{bn}$, with Belgium underwriting $€ 2.915 \mathrm{bn}$ and France underwriting $€ 2.585 \mathrm{bn}^{10}$. This takes the overall amount of the recapitalization to $€ 11.5$ bn. As with the case of BFA/Bankia, all measures were channelled through the parent company, in this case Dexia S.A., usually referred to as Dexia Group.

Give the above we can definitely classify this case as a bail out but performed at the center.

\section{Bank of Cyprus ${ }^{11}$}

The Bank of Cyprus was under resolution from 25 March 2013 until 30 July 2013 by the Central Bank of Cyprus, which acts as the resolution authority. The resolution was implemented via the bail-in of uninsured depositors (deposits above the $€ 100.000$ threshold covered by deposit insurance) through a conversion of $47.5 \%$ of such deposits into equity. Additionally, holders of debt securities and ordinary shares issued by the Bank as of the beginning of the resolution period contributed to the recapitalization of the bank through the absorption of losses. The total amount of money involved in the bail-in was estimated by the IMF (based also on the Central Bank of Cyprus) at $€ 4.5 \mathrm{bn}$, of which $€ 3.9$ bn and $€ 0.6$ bn corresponded respectively to uninsured deposits and subordinated debt.

\section{Fortis $^{12}$}

The Fortis Group went through a substantial restructuring in 2008, involving participation from the three Benelux states. On 29 September 2008 the Belgian Government acquired 49.93\% of Fortis Bank Belgium for $€ 4.7 \mathrm{bn}$, whereas the Government of Luxembourg agreed to invest $€ 2.5$

ing of the Dexia Group, the amount reported is $€ 5.4 \mathrm{bn}$. Given this we have chosen to stick to the most recent information which is contained in the article from the Official Journal of the EU.

${ }^{10}$ As of 31 December 2013, the Belgian state is the major stakeholder at Dexia group, owning $50 \%$ of the shares, whereas France's stake is at $44.4 \%$.

${ }^{11}$ Sources: Bank of Cyprus (p120,p200), IMF, Finpolconsult, Central Bank of Cyprus.

${ }^{12}$ Links: Fortis (p46), European Commission (II, III, IV). 


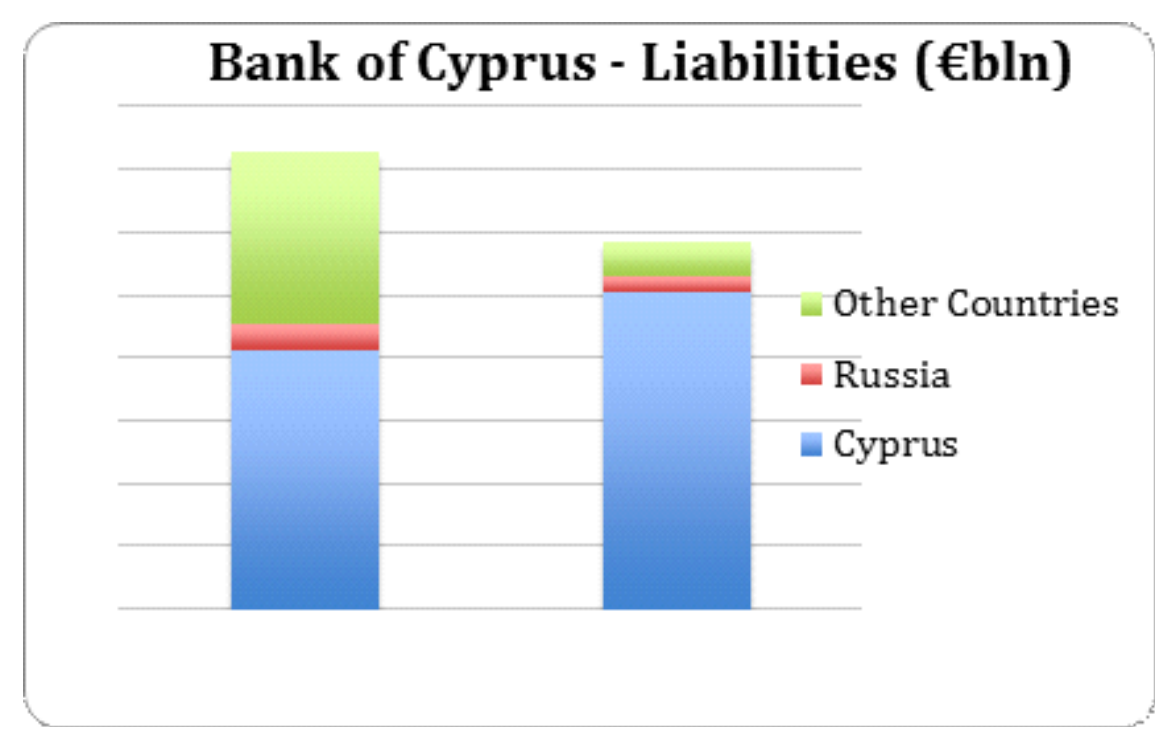

Figure 4: Source: Bank of Cyprus Annual Report 2013, p68.

bn in Fortis Banque Luxembourg. On 10 October 2008 the Belgian Government acquired the rest of Fortis Bank Belgium for an additional $€ 4.7$ bn.

On 3 October 2008 the Government of the Netherlands acquired Fortis Bank Netherlands for $€ 16.8 \mathrm{bn}^{13}$. On 19 July 2009 the Government of the Netherlands announced a recapitalization for ABN AMRO worth $€ 2.5 \mathrm{bn}$, and on 15 January 2010 a further recapitalization worth $€ 4.39$ bn in favor of ABN AMRO and Fortis Bank Netherlands was announced.

This case, like Dexia, also falls in the category of bail-outs with coordinated authorities.

\section{Amagerbanken ${ }^{14}$}

Amagerbanken filed for bankruptcy and was declared bankrupt on 7 February 2011, after a loss-recognition exercise that derived in the bank having negative equity. The bank was taken over the by the Financial Stability Company (FSC), which is the State-owned winding-up agency. All assets and certain liabilities were transferred to a new bank ("Amagerbanken af 2011 A/S"), most of which was eventually resold.

Prior to the events in February 2011 Amagerbanken had received support from the Danish

\footnotetext{
${ }^{13}$ This transaction involved also the participation Fortis Bank Netherlands in RFS Holdings (which included ABN AMRO), Fortis Insurance Netherlands and Fortis Corporate Insurance.

${ }^{14}$ Sources: Finansiel Stabilitet Annual Report 2011, European Commision (II, III), Danmarks Nationalbank.
} 
State: a drawing right from the Danish Central Bank (€ 403 million), a capital injection approved by the Commission on 3 February 2009 (€ 148 million), and an individual State Guarantee of $€$ 1.8 billion within the framework of the Danish Guarantee Scheme. Of this Guarantee roughly $€$ 277 million were eventually a loss for the Danish State (see Financial Stabilitet report 2011 of the Danish State, p37).

At the time of the transfer to the national authorities, the FSC provided an equity injection of $€ 161$ million to the new bank in order to enable it to meet regulatory requirements. An additional $€ 203$ million were injected as share capital into Amagerbanken at the time of transfer, due to uncertainty about the initial assessment of risk-weighted assets.

An additional feature of the Amagerbanken resolution is the bail-in of senior debt and unsecured depositors. The losses borne by this group amounted to roughly $€ 110$ million (see footnote 5 European Commission letter, 25.01.2012

$\mathrm{C}(2012)$ 148). The total losses are calculated then as the sum of the bailed-in money, the loss on the guarantee, the two capital injections at the time of transfer and the capital injection prior to the transfer. This sums to $€ 0.9$ billion.

\section{Banco Espirito Santo (BES)}

Banco Espirito Santo S.A. was as of end June 2014 the third largest banking group in Portugal. It is a universal bank incorporated and domiciled in Portugal, though it is part of a larger group with a large international reach ${ }^{15}$, plus the BES group itself has a stake in subsidiaries in different countries. It is indeed a quite complex cross-border structure.

Intra-group exposures were the trigger of stress in BES, which on July 302014 announced losses well beyond expected values (€3.6 billion) ${ }^{16}$ based on previously available information. As a result BES found itself out of compliance with minimum capital requirements and, following a brief period of high stress and uncertainty, forced the Bank of Portugal to engineer a restructuring/recapitalization plan, as BES is considered a systemically important institution.

The restructuring plan, which was speedily approved by the European Commission, essentially

\footnotetext{
${ }^{15}$ Again as of June 2014, BES was $25 \%$ owned by Espirito Santo Financial Group (ESFG), in turn $49.3 \%$ owned by RioForte, in turn owned in full by Espirito Santo International (ESI).

${ }^{16}$ For a more detailed account of the structure of whole group and the exposure of BES to different parts of it see http://www.pieria.co.uk/articles/how_to_rip_off_a_bank_esprito_santo_style and http://www.bruegel.org/nc/blog/detail/article/1412-fact-banco-espirito-santo-gets-a-4-billion-euro-recap/.
} 
splits the bank in two. BES remains a "bad bank" and keeps shareholders and subordinated debtors. The latter will be written down against the bad assets from the intra-group exposures. This action effectively formalized the bail-in arrangement for this case ${ }^{17}$. Essentially all other balance sheet items will be transferred to a new "good bank", created to guarantee continuity of the healthy part of BES business ${ }^{18}$. Novo Banco inherits from BES its deposits, healthy assets and senior bondholders. Notice that bondholders have not been bailed in, a decisions which could actually be seen as contradicting the spirit of the recently approved BRRD, which will enter into force in January 2015. According to data presented by Novo Banco, at the time of transfer (and for BES at the individual level) the capital that was not transferred amounted to $€ 6$ billion $^{19}$, plus $€ 902$ million of unsubordinated debt.

Importantly, the equity capital of Novo Banco, which amounts to $€ 4.9$ billion, is fully underwritten by Portugal's Resolution Fund. The issue here is that since the Fund was established only recently (2012) it lacks the sufficient funds to bear the costs of the operation, hence most of the equity capital ( $€ 4.4$ billion) is financed through a loan from the Portuguese government (via the Resolution Fund). This case could therefore be classified as bail in, but since part of the equity capital was obtained through state loans there is a possibility in the future that some losses might be borne by taxpayers.

\section{Conclusions}

One of the most important revolution which took place following the 2007-2009 financial crisis has been the re-design of resolution regimes which nowadays in most countries take the form of bail-in procedures with single point of entry regimes. The policy debate which led to the design of this regime lacked so far an analytical framework. We provide one by constructing a model with banks operating via liquidity and equity requirements and resolution authorities. We compare different resolution regimes in the form of bail in with multiple versus single point of entry. We furthermore explore the consequences of the different resolution regimes for the banks' cross-border activity.

\footnotetext{
${ }^{17}$ This troubled assets are essentially the liabilities of other entities of the Grupo Espirito Santo and of Banco Espirito Santo Angola S.A..

${ }^{18}$ The name of the newly created institution is Novo Banco, which literally means "new bank".

${ }^{19}$ This amount goes to $€ 4$ billion after other adjustments made to total capital.
} 
We complement our theoretical analysis with a qualitative and quantitative description of some recent resolution cases which in some cases exemplify the single point of entry regime.

\section{References}

[1] Claessens, S., Herring, R. J. and Schoenmaker, D., (2010). A Safer World Financial System: Improving the Resolution of Systemic Institutions. Geneva report.

[2] Diamond D. W. and Dybvig P.H. (1983). "Bank runs, deposit insurance, and liquidity". Journal of Political Economy, 91 (3): 401-419.

[3] European commission (2014), EU Bank Recovery and Resolution Directive (BRRD): FAQ, April 15, 2014. http://europa.eu/rapid/press-release_MEMO-14-297_en.htm

[4] FDIC and BOE (2012) Resolving Globally Active, Systemically Important Financial Institutions, http://www.bankofengland.co.uk/publications/Documents/news/2012/nr156.pdf

[5] FSB (2013) Recovery and Resolution Planning for Systemically Important Financial Institutions: Guidance on Developing Effective Resolution Strategies http://www.financialstabilityboard.org/publications/r_130716b.pdf

[6] Niepmann, F. and Schmidt-Eisenlohr, T., (2013). "Bank Bailouts, International Linkages, and Cooperation." American Economic Journal: Economic Policy, vol. 5(4), pages 270-305.

[7] Huertas Thomas (2014) Safe to Fail, How Resolutions will Revolutionize Banking. Palgrave McMillan.

[8] Steve Ongena, (20xx), When the cats away the mice will play: does regulation at home affect bank risk-taking abroad? Journal of Financial Economics, 108

[9] Schoenmaker Dirk and W Wagner (2011). The Impact of Cross Border Banking https://www.econstor.eu/dspace/bitstream/10419/86674/1/11-054.pdf

[10] Tucker P. (2013), Solving too big to fail: Where do things stand on resolution, Speech at the Institute of International Finance, Annual membership meeting, October 12, 2013. http://www.bankofengland.co.uk/publications/Documents/speeches/2013/speech685.pdf 
[11] Turner Review (2009) 


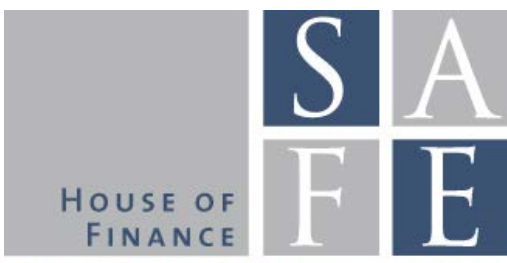

WORKING PAPER SERIES

\section{Recent Issues}

No. 87 Iñaki Aldasoro, Domenico Delli Gatti, Ester Faia

No.86 Agar Brugiavini, Danilo Cavapozzi, Mario Padula, Yuri Pettinicchi

No. 85 Holger Kraft, Claus Munk, Sebastian Wagner

No. 84 Raimond Maurer, Olivia S. Mitchell, Ralph Rogalla, Tatjana Schimetschek

No.83 Patrick Grüning

No. 82 Edgar Vogel, Alexander Ludwig, Axel Börsch-Supan

No. 81 Jens-Hinrich Binder

No. 80 Enrique G. Mendoza, Linda L. Tesar, Jing Zhang

No. 79 Òscar Jordà, Alan M. Taylor

No. 78 Harris Dellas, Dirk Niepelt

No. 77 Benjamin Born, Gernot J. Müller, Johannes Pfeifer

No.76 Alberto Alesina, Carlo Favero, Francesco Giavazzi

No. 75
Markus Behn, Rainer Haselmann, Vikrant Vig
Bank Networks: Contagion, Systemic Risk and Prudential Policy

Financial education, literacy and investment attitudes

Housing Habits and Their Implications for LifeCycle Consumption and Investment

Will They Take the Money and Work? An Empirical Analysis of People's Willingness to Delay Claiming Social Security Benefits for a Lump Sum

International Endogenous Growth, Macro Anomalies, and Asset Prices

Aging and Pension Reform: Extending the Retirement Age and Human Capital Formation

Resolution Planning and Structural Bank Reform within the Banking Union

Saving Europe?: The Unpleasant Arithmetic of Fiscal Austerity in Integrated Economies

The Time for Austerity: Estimating the Average Treatment Effect of Fiscal Policy

Austerity

Does Austerity Pay Off?

The Output Effect of Fiscal Consolidation Plans

The Limits of Model-Based Regulation 